\title{
Mammals of medium and large size in Cerrado remnants in southeastern Brazil
}

\section{Mamíferos de médio e grande porte em remanescentes de Cerrado de Minas Gerais, Brasil}

\author{
Rafael de Souza Laurindoํㅜㄹ Flávia Regina Nascimento Toledo², \\ Elias Manna Teixeira ${ }^{2}$
}

1 Departamento de Biologia, Universidade Federal de Lavras, Minas Gerais, Brazil

2 Centro Universitário UNA. Uberlândia, Minas Gerais, Brazil

Corresponding author: Rafael de Souza Laurindo (rafaelslaurindo@gmail.com)

Academic editor:A.M. Leal-Zanchet | Received 19November 2018 | Accepted 31 March 2019| Published 15 July 2019

Citation: Laurindo RS, Toledo FRN, Teixeira EM (2019) Mammals of medium and large size in Cerrado remnants in southeastern Brazil. Neotropical Biology and Conservation 14(2): 195-206. https://doi.org/10.3897/ neotropical.14.e37653

\begin{abstract}
The Cerrado is the second largest biome in Brazil and considered a global biodiversity hotspot due to its high species richness, elevated amount of endemisms, and several anthropogenic threats. The Cerrado has more than 250 species of mammals, and about $15 \%$ are endemic. However, fragmentation and the consequent loss of native habitat threaten the maintenance of mammalian populations. In this context we carried out an inventory of medium- and large-sized mammals in Cerrado remnants in Matutina, Minas Gerais, southeastern Brazil. Sampling was performed in four remnants of Cerrado and adjacent agricultural matrices for 18 days and 16 nights in March and July 2015 with camera traps, diurnal and nocturnal censuses, and by searching for tracks and other indirect evidence. We recorded 19 species of mammals, including top predators and species vulnerable to extinction. The original vegetation cover in the study area has become severely reduced and fragmented due to agricultural expansion. However, the remnants still retain considerable diversity of medium- and large-sized mammals, making them important for the maintenance of biological diversity.
\end{abstract}

\section{Resumo}

O Cerrado é o segundo maior bioma brasileiro, sendo considerado um hotspot de biodiversidade global devido à sua alta riqueza de espécies, elevada quantidade de endemismos e várias ameaças 
antrópicas. Há registro de mais de 250 espécies de mamíferos para o Cerrado, 15\% delas endêmicas. Contudo, a fragmentação e a consequente perda de habitat nativo ameaçam a manutenção de suas populações de mamíferos. Nesse contexto, realizamos um inventário de mamíferos de médio e de grande porte em remanescentes de Cerrado em Matutina, Minas Gerais, Brasil. Nos meses de março e julho de 2015 foram realizados 18 dias e 16 noites de amostragem através de armadilhas fotográficas, censo diurno e noturno, e busca por vestígios. Registramos 19 espécies de mamíferos, incluindo predadores de topo de cadeia e espécies vulneráveis à extinção. A região estudada sofreu uma severa redução e fragmentação da cobertura vegetacional original devido à expansão da agropecuária. Contudo, os remanescentes ainda conservam uma considerável parcela da diversidade de mamíferos de médio e grande porte, sendo importantes para a manutenção da diversidade biológica.

\section{Keywords}

agricultural mosaic, camera trap, Brazilian savanna, mammal fauna

\section{Palavras-chave}

armadilha fotográfica, mastofauna, mosaico agrícola, savana brasileira

\section{Introduction}

The Cerrado (Brazilian savanna) is the second largest morphoclimatic domain in South America and comprises a mosaic of savanna phytophysiognomies that cover an area of more than two million square kilometers, which is equivalent to $23 \%$ of the extension of the Brazilian territory (Silva et al. 2006). Due to the expansion of agriculture and severe reduction and fragmentation of native habitats, the Cerrado is considered one of the most endangered tropical savannas in the world (Silva and Bates 2002). Estimates made at the beginning of the $21^{\text {st }}$ century indicated that approximately $55 \%$ of the original vegetation cover was destroyed by anthropic activities, mainly to grow soybeans, corn, sugar cane and eucalyptus and to create pastures (Klink and Machado 2005).

Indeed, the Cerrado has high species richness and high rates of endemism, which makes it a global biodiversity hotspot (Myers et al. 2000; Klink and Machado 2005). More than 250 species of mammals have been recorded in this domain and about 15\% of them are endemic (Paglia et al. 2012, Gutiérrez and Marinho-Filho 2017). However, the fragmentation and consequent loss of native habitat threatens the maintenance of mammal populations, especially the larger species (Silva and Diniz-Filho 2008). Additional studies are needed to understand the magnitude of the damage caused to biodiversity due to the destruction of the Cerrado. Based on this, species surveys are at the forefront of the biological sciences, since they reduce the Wallacean shortfall and allow the construction of conservation plans (Whittaker et al. 2005; Oliveira et al. 2009a).

Many inventories of large- and medium-sized mammals have been conducted in conservation units (CUs) (Rodrigues et al. 2002; Câmara and Oliveira 2012; Leite et al. 2016; Cabral et al. 2017); however, only 8.34\% of the Cerrado is part of the system of protected areas (Françoso et al. 2015). Most of the mammal populations are 
outside of CUs and are more susceptible to anthropic impacts. Previous studies have demonstrated that some species of large- and medium-sized mammals may be able to persist in fragmented landscapes in the Cerrado by using different agricultural matrices to move between patches of native vegetation. However, severe loss of native vegetation may be a crucial obstacle to the long-term survival of some species (Crooks et al. 2011).

In this context, we present here the results of a survey of medium-sized and large mammals in Cerrado remnants immersed in an agricultural landscape in the Triângulo Mineiro. The Triângulo Mineiro and Alto Paranaíba are regions in the Cerrado domain, in the state of Minas Gerais, with scarce records of mammal species. In addition, these regions have large areas of pasture, sugarcane and soybean crops that have replaced significant areas of the Cerrado (Drumond et al. 2005).

\section{Material and methods}

The study was conducted at Fazenda Ferreiros, in the municipality of Matutina, Minas Gerais, southeastern Brazil $\left(19^{\circ} 08^{\prime} \mathrm{S}, 46^{\circ} 03^{\prime} \mathrm{W}\right.$, Fig. 1$)$. The study area comprises fragments of seasonal forest, gallery forest along water courses and anthropic areas destined to be pasture. The climate is tropical savanna (subtype Aw), with a hot and rainy summer from October to March and dry winter from April to September (Reboita et al. 2015).

Sampling was carried out in four remnants of Cerrado and adjacent agricultural matrices for eight consecutive days in March and July 2015 (totaling 18 days and 16 nights sampling). The medium and large mammals were sampled using three methods. The first method was an active daytime search, where walks were taken in each Cerrado fragment on trails that were between 650 and 1,500 meters (depending on the fragment). A distance of 2,000 meters was also traversed in the matrix adjacent to the remnants of Cerrado. The active daytime search consisted of recording direct (observation) and indirect (footprints, feces, and burrows) signs. Each fragment was sampled for two days, one in the dry season and the other in the rainy season. The second method was a nocturnal census, carried out with a vehicle and an observer with a spotlight. This survey covered a total of 7,000 meters per night. The census was carried out on roads that pass close to the forest fragments and also the agricultural matrices. The nocturnal censuses were performed on six nights, three in the dry season and three in the rainy season, totaling 42,000 meters. Finally, two camera traps (Bushnell ${ }^{\circ}$ Trophy Cam) were installed in each of the four fragments. One trap was located inside the fragment and another one was on the border, directed to the adjacent matrix; the average distance between the two cameras was $403 \mathrm{~m}$ (minimum $=287 \mathrm{~m}$, maximum $=518 \mathrm{~m}$ ). Each photographic trap remained active for 24 hours for six nights and eight consecutive days, resulting in a total sampling effort of 48 cameras/night.

We used field guides to help the identification of traces found in the field (e.g., Becker and Dalponte 1999; Borges and Tomás 2005; Mamede and Alho 2008). The taxonomic nomenclature used was standardized according to Paglia et al. (2012). 

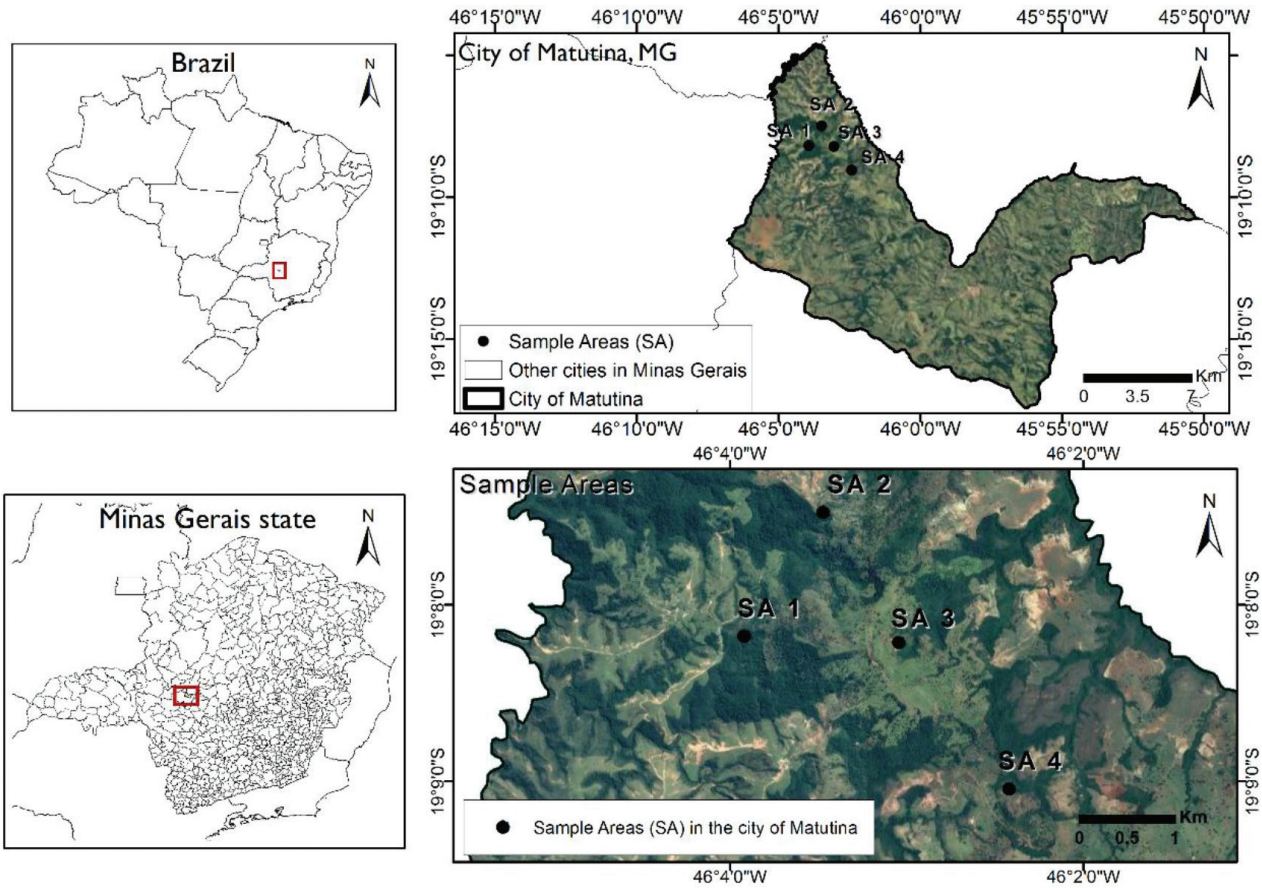

Figure 1. Study sites in remnants of Cerrado in southern Minas Gerais, southeastern Brazil. Points represent the sampled locations.

We constructed a species accumulation curve with 1,000 iterations. To estimate the expected species richness, we used the first-order Jackknife (Jackknife-1), a non-parametric estimator in the program EstimateS version 8.0. To elaborate the curve and to estimate the species richness, we evaluated the presence and absence data of the species in the sampled sites.. Exotic species were excluded from the statistical analyses.

\section{Results}

We recorded 19 species of medium-sized and large mammals, including 17 native species and two exotic species, distributed in six orders and 12 families (Table 1, Fig. 2). Carnivora was the most representative order with 10 species, corresponding to $52 \%$ of the total number of species, followed by Primates with three species (17.6\%).

The search for indirect traces (mainly footprints) was the most efficient methodology; ten species were recorded using this method. Camera traps and direct observations during the censuses recorded five species each. Myrmecophaga tridactyla and Dasyprocta azarae were recorded only by camera trap, Callithrix penicillata and Conepatus semistriatus were directly observed during the day and night censuses, and the other eight species were recorded from indirect traces (Table 1). 
Table 1. List of large- and medium-sized mammals in an area of Cerrado in Matutina, Minas Gerais, Brazil. Record type: [1] camera trap, [2] footprint, [3] direct observation, [4] vocalization. Habitat: [1] forest fragment, [2] agricultural matrix (pasture). ${ }^{\star}$ domestic species.

\begin{tabular}{|c|c|c|c|}
\hline Taxon & Vernacular name & Record & Habitat \\
\hline \multicolumn{4}{|l|}{ Carnivora } \\
\hline \multicolumn{4}{|l|}{ Canidae } \\
\hline Canis familiaris* & Domestic dog & {$[2][3]$} & {$[1][2]$} \\
\hline Cerdocyon thous & Crab-eating Fox & {$[2]$} & [1] [2] \\
\hline \multicolumn{4}{|l|}{ Felidae } \\
\hline Felis catus* & Domestic cat & [3] & [2] \\
\hline Leopardus pardalis & Ocelot & [1] [2] & [1] [2] \\
\hline Puma concolor & Puma & {$[2]$} & {$[2]$} \\
\hline \multicolumn{4}{|l|}{ Mephitidae } \\
\hline Conepatus semistriatus & Striped Hog-nosed Skunk & [3] & [2] \\
\hline \multicolumn{4}{|l|}{ Mustelidae } \\
\hline Eira barbara & Tayra & {$[1][2]$} & {$[1][2]$} \\
\hline Galictis cuja & Lesser Grison & {$[2]$} & [1] \\
\hline Lontra longicaudis & Neotropical Otter & [2] & [1] \\
\hline \multicolumn{4}{|l|}{ Procyonidae } \\
\hline Nasua nasua & South American Coati & [2] & [1] [2] \\
\hline Procyon cancrivorus & Crab-eating Racoon & [2] & [1] \\
\hline \multicolumn{4}{|l|}{ Cingulata } \\
\hline \multicolumn{4}{|l|}{ Dasypodidae } \\
\hline Dasypus novemcinctus & Nine-banded Armadillo & [2] & {$[1][2]$} \\
\hline \multicolumn{4}{|l|}{ Lagomorpha } \\
\hline \multicolumn{4}{|l|}{ Leporidae } \\
\hline Sylvilagus brasiliensis & Tapeti & {$[1][3]$} & [2] \\
\hline \multicolumn{4}{|l|}{ Pilosa } \\
\hline \multicolumn{4}{|l|}{ Myrmecophagidae } \\
\hline Myrmecophaga tridactyla & Giant Anteater & [1] & [2] \\
\hline \multicolumn{4}{|l|}{ Primates } \\
\hline \multicolumn{4}{|l|}{ Callitrichidae } \\
\hline Callithrix penicillata & Black-pencilled Marmoset & [3] & [1] \\
\hline \multicolumn{4}{|l|}{ Cebidae } \\
\hline Sapajus libidinosus & Bearded Capuchin & {$[3][4]$} & [1] \\
\hline \multicolumn{4}{|l|}{ Pitheciidae } \\
\hline Callicebus nigrifrons & Black-fronted Titi Monkey & [3] [4] & [1] \\
\hline \multicolumn{4}{|l|}{ Rodentia } \\
\hline \multicolumn{4}{|l|}{ Caviidae } \\
\hline Hydrochoerus hydrochaeris & Capybara & [2] & [1] [2] \\
\hline \multicolumn{4}{|l|}{ Dasyproctidae } \\
\hline Dasyprocta azarae & Azara's Agouti & [1] & [1] \\
\hline
\end{tabular}

The species accumulation curve indicates that the continuity of sampling should add new species to the list. The estimated richness of Jackknife-1, based on the sampling, was 24 species $( \pm 2)$, showing that the richness observed represented $70 \%$ of the total species expected for the site (Fig. 3).

Considering the type of environment, seven species were recorded only in forest fragments, four species were exclusive to agricultural matrices and six species were recorded in both environments (Table 1). 

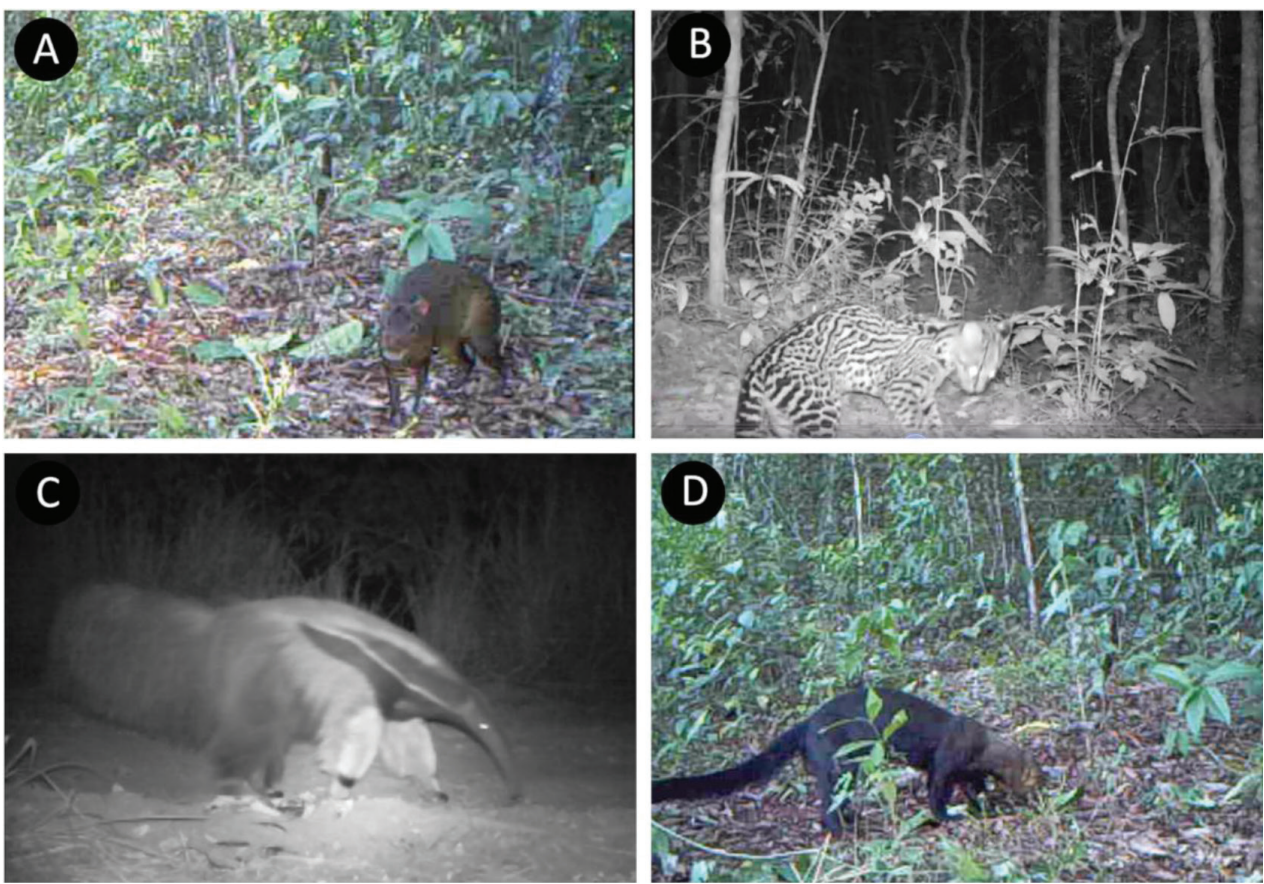

Figure 2. Records made from camera traps at Fazenda Ferreiros, Matutina, Minas Gerais, southeastern Brazil: (A) Dasyprocta azarae; (B) Leopardus pardalis; (C) Myrmecophaga tridactyla; (D) Eira barbara.

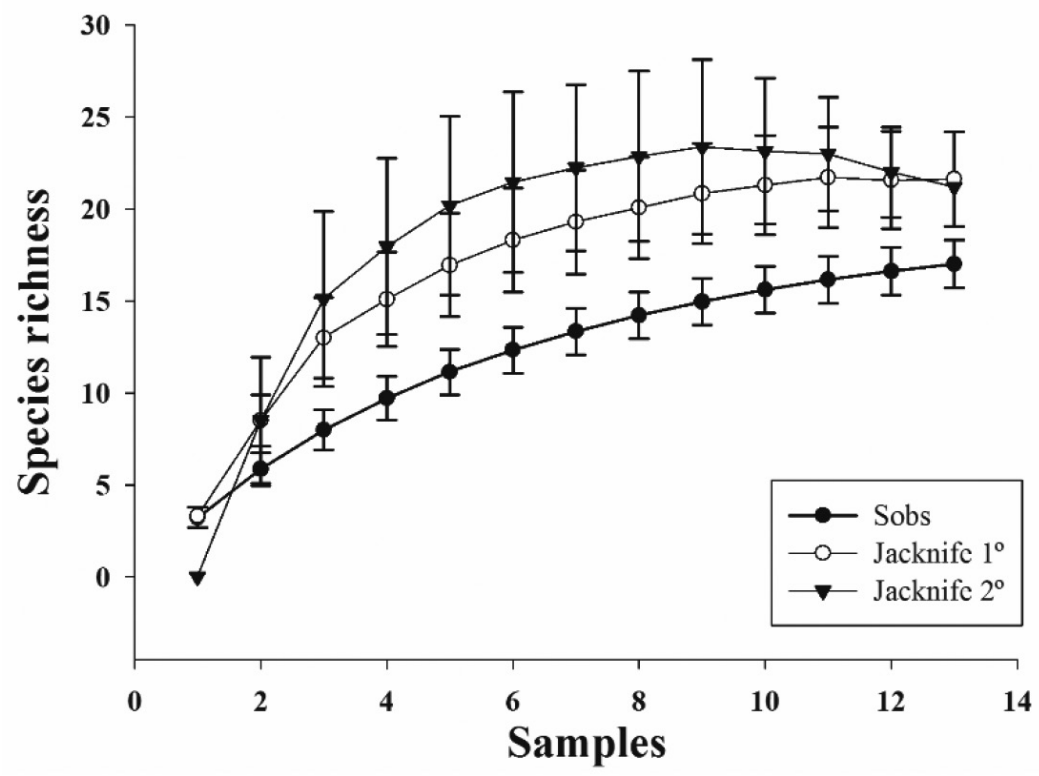

Figure 3. Species accumulation curve (solid line) and richness estimator (dashed line) for mediumand large-sized mammals at Fazenda Ferreiros, Matutina, Minas Gerais, southeastern Brazil. 


\section{Discussion}

Studies conducted both in conservation units (CUs) and outside protected areas have recorded high mammal richness in the Cerrado. Depending on the locality, richness has varied between 17 and 27 species in CUs (Oliveira et al. 2009b; Leite et al. 2016; Cabral et al. 2017) and between 15 and 25 species on private property (Cáceres et al. 2010; Lessa et al. 2012; Estrela et al. 2015). Thus, the richness of medium-sized and large mammals recorded in the present study agrees with other studies carried out in areas of Cerrado in Brazil (Rocha and Dalponte 2006).

The highest species richness for Carnivora, as recorded in the present study, was expected, since this order has the largest number of species of medium-sized and large mammals in the Cerrado (Paglia et al. 2012). The presence of domestic dogs and cats living in the interior and surrounding Cerrado remnants is a potential threat to local biodiversity (Paschoal et al. 2012). In addition to predation, feral dogs and cats can spread diseases in wild animals (Curi et al. 2010; Loss et al. 2013).

The occurrence of Puma concolor is notable. This species is a top predator that plays an important role in maintaining the trophic web, since it has an extensive range and needs large habitats to survive (Maehr et al.2002). Similarly to other large mammals, $P$. concolor is negatively affected by fragmentation and loss of habitat (Morrison et al. 2007). The fragments in the study area are probably insufficient to maintain a population of large-sized carnivores, being just used as a corridor.

Two other notable species are Leopardus pardalis and Myrmecophaga tridactyla. Leopardus pardalis feeds on smaller rodents and marsupials, as well as larger prey, such as primates, armadillos and reptiles (Bianchi et al. 2010), helping the control of their population densities (Fonseca and Robinson 1990; Terborgh 2000). Myrmecophaga tridactyla is a species considered vulnerable to extinction at the national and international level (Miranda et al. 2014).

Despite the advance of agriculture and livestock farming in the region, the four remnants that we studied preserve an important portion of medium-sized and large mammals of the Cerrado biome. Studies show that some species of medium and large mammals can use landscapes formed by forest fragments and agricultural areas, and that they explore both native vegetation and agricultural matrices (Trolle et al. 2007, Lyra-Jorge et al. 2008, Bruna et al. 2010). However, the survival of these species over the long-term depends on the amount of available habitat, matrix type and size and connectivity of the fragments (Carvalho et al. 2009; Rocha et al. 2018). It is important to note that the absence of seed dispersers, such as Tapirus terrestres and Tayassu pecari, and the loss of large-sized frugivores can negatively affect the recruitment and survival of plant species, mainly those showing fruits with large seeds (Galetti et al. 2015).

Small fragments of native vegetation in landscapes modified by humans have been considered refuges for local fauna (Melo et al. 2013) and may harbor high species richness, including endangered species (Laurindo et al. 2017). In the present study, seven species were recorded exclusively from forest fragments, which could 
be linked to the biological characteristics of the species (e.g., primates have an arboreal habit and are generally not found in pastures) or to habitat preference (e.g., Lontra longicaudis is a semiaquatic species and, in this study, was only recorded in the interior of riparian forests). Thus, it is important to develop conservation strategies to increase the functional connectivity of these areas, through the creation of corridors and stepping stones to connect these remnants, as well as strategies to manage the agricultural matrices.

The combination of different sampling methods (e.g., camera trap, census, and trail search) proved to be efficient at recording considerable species richness in a short sampling period, which reinforces the importance of combining different methodologies to increase sampling success. According to Carvalho et al. (2016), the most efficient methods to sample medium- and large-sized mammals involved searching for indirect (footprints, feces, and burrows) and direct (observation) records. Both in our study and in Carvalho et al. (2016), camera traps recorded approximately half of the species found by other methods, indicating the need for methodological variability for survey studies. Still, the use of camera traps is an important methodology for recording cryptic and less abundant species, which are rarely detected by other methods (Melo et al. 2012). In long-term studies, the use of camera traps is extremely advantageous, since it is the cheapest method, does not require the presence of a researcher during sampling and increases the chances of correctly identifying species compared to footprints (Carvalho et al. 2016). Mazza et al. (2018), in a study in RPPN Alto-Montana in southern Minas Gerais, continuously used camera traps for three years and recorded 21 native and four exotic species of medium- and large-sized mammals.

We also emphasize the importance of daytime censuses for direct observation, especially for primates, since both camera traps and searching for indirect traces may underestimate the presence of this group due to the arboreal habit. In this study, three primate species were recorded through visualization and vocalizations during the daytime censuses.

Although the medium- and large-sized mammal fauna represents one of the best studied groups in the world, for many species there are still knowledge gaps about distribution, habitat use and persistence after habitat destruction, especially in the Neotropics. Thus, faunal inventories are still of inestimable importance and may be the only information about the biodiversity of an area at risk of disappearing in a short time.

\section{Acknowledgments}

We thank T.O.S. Lobato, D.T.S. Peixoto and J.R. Gonçalves for helping with fieldwork, Manna \& Toledo Planejamento Ambiental Ltda. for the logistical support, and the Grupo Funchal e Fazenda Ferreiros for permission to use the data, to anonymous referees for the valuable suggestions. RSL thanks CAPES for the doctoral fellowship. 


\section{References}

Becker M, Dalponte JC (1999) Rastros de mamíferos silvestres brasileiros: um guia de campo. Editora da Universidade de Brasília, Brasília, 180pp.

Bianchi RDC, Mendes SL, Júnior PDM (2010) Food habits of the ocelot, Leopardus pardalis, in two areas in southeast Brazil. Studies on Neotropical Fauna and Environment 45(3): 111-119. https://doi.org/10.1080/01650521.2010.514791

Borges PA, Tomás WM (2005) Guia de rastros e outros vestígios de mamíferos do Pantanal. EMBRAPA Pantanal, Corumbá, 86pp.

Bruna EM, Guimarães JF, Lopes CT, Duarte P, Gomes ACL, Lelentani SCS, Pacheco R, Facure KG, Lemos FG, Vasconcelos HL (2010) Mammalia, Estação Ecológica do Panga, a Cerrado protected area in Minas Gerais state, Brazil. Check List 6(4): 668-675. https:// doi.org/10.15560/6.4.668

Cabral R, Zanin M, Porfírio G, Brito D (2017) Medium-sized to large mammals of Serra do Tombador, Cerrado of Brazil. Check List 13(3): 2129. https://doi.org/10.15560/13.3.2129

Cáceres NC, Nápoli RP, Casella J, Hannibal W (2010) Mammals in a fragmented savannah landscape in south-western Brazil. Journal of Natural History 44(7-8): 491-512. https:// doi.org/10.1080/00222930903477768

Câmara EMVC, Oliveira L (2012) Mammals of Serra do Cipó National Park, southeastern Brazil. Check List 8(2): 355-359. https://doi.org/10.15560/8.3.355

Carvalho FM, Júnior PDM, Ferreira LG (2009) The Cerrado into-pieces: Habitat fragmentation as a function of landscape use in the savannas of central Brazil. Biological Conservation 142(7): 1392-1403. https://doi.org/10.1016/j.biocon.2009.01.031

Carvalho WD, Rosalino LM, Adania CH, Esbérard CEL (2016) Mammal inventories in Seasonal Neotropical Forests: Traditional approaches still compensate drawbacks of modern technologies. Iheringia. Série Zoologia 106(0): e2016005. https://doi.org/10.1590/1678$4766 \mathrm{e} 2016005$

Crooks KR, Burdett CL, Theobald DM, Rondinini C, Boitani L (2011) Global patterns of fragmentation and connectivity of mammalian carnivore habitat. Philosophical Transactions of the Royal Society of London. Series B, Biological Sciences 366(1578): 26422651. https://doi.org/10.1098/rstb.2011.0120

Curi NH, Araújo AS, Campos FS, Lobato ZIP, Gennari SM, Marvullo MFV, Silva JCR, Talamoni SA (2010) Wildcanids, domestic dogs and their pathogens in southeast Brazil: Diseasethreats for canid conservation. Biodiversity and Conservation 19(12): 35133524. https://doi.org/10.1007/s10531-010-9911-0

Drumond GM, Martins CS, Machado ABM, Sebaio FA, Antonini Y (2005) Biodiversidade em Minas Gerais: um atlas para sua conservação. Fundação Biodiversitas, Belo Horizonte, $222 \mathrm{pp}$.

Estrela DC, Souza DC, Souza JM, Castro ALS (2015) Medium and large-sized mammals in a Cerrado area of the state of Goiás, Brazil. Check List 11(4): 1690. https://doi. org/10.15560/11.4.1690

Fonseca GAB, Robinson JG (1990) Forest size and structure: Competitive and predatory effects on small mammal communities. Biological Conservation 53(4): 265-294. https:// doi.org/10.1016/0006-3207(90)90097-9 
Françoso RD, Brandão R, Nogueira CC, Salmona YB, Machado RB, Colli GR (2015) Habitat loss and the effectiveness of protected areas in the Cerrado Biodiversity Hotspot. Natureza \& Conservação 13(1): 35-40. https://doi.org/10.1016/j.ncon.2015.04.001

Galetti M, Bovendorp RS, Guevara R (2015) Defaunation of large mammals leads to an increase in seed predation in the Atlantic forests. Global Ecology and Conservation 3: 824-830. https://doi.org/10.1016/j.gecco.2015.04.008

Gutiérrez EE, Marinho-Filho JS (2017) The mammalian faunas endemic to the Cerrado and Caatinga. ZooKeys 644: 105-157. https://doi.org/10.3897/zookeys.644.10827

Klink CA, Machado RB (2005) Conservation of the Brazilian Cerrado. Conservation Biology 19(3): 707-713. https://doi.org/10.1111/j.1523-1739.2005.00702.x

Laurindo RS, Novaes RLM, Souza RF, Souza VF, Felix F, Souto TM, Grassetto RTC, Gregorin $\mathrm{R}$ (2017) Mammals in forest remnants of an ecotonal Atlantic Forest-Cerrado area from southeastern Brazil. Neotropical Biology and Conservation 12(1): 19-29. https://doi. org/10.4013/nbc.2017.121.03

Leite RJV, Lemos JLF, Silva FWMD, Alencar IRCD, Bezerra PF, Carregaro JB (2016) Composition of medium and large mammals in forest reserve in the Cerrado of Brazil Central. Revista Árvore 40(5): 825-832. https://doi.org/10.1590/0100-67622016000500006

Lessa L, Alves H, Geise L, Barreto RMF (2012) Mammals of medium and large size in a fragmented cerrado landscape in northeastern Minas Gerais, Brazil. Check List 8(2): 192-196. https://doi.org/10.15560/8.2.192

Loss SR, Will T, Marra PR (2013) The impact of free-ranging domestic cats on wildlife of the United States. Nature Communications 4(1): e1396. https://doi.org/10.1038/ ncomms 2380

Lyra-Jorge MC, Ciocheti G, Pivello VR (2008) Carnivore mammals in a fragmented landscape in northeast of Sao Paulo State, Brazil. Biodiversity and Conservation 17(7): 1573-1580. https://doi.org/10.1007/s10531-008-9366-8

Maehr DS, Land ED, Shindle DB, Bass OL, Hoctor TS (2002) Florida panther dispersal and conservation. Biological Conservation 106(2): 187-197. https://doi.org/10.1016/S00063207(01)00245-2

Mamede SB, Alho CJR (2008). Impressões do Cerrado e Pantanal: subsídios para a observação de mamíferos silvestres não voadores, $2^{\text {a }}$ edição. Editora da UFMS, Campo Grande, 208pp.

Mazza I, Rosa CA, Souza AC, Aximoff I, Passamani M (2018) Mamíferos de médio e grande porte registrados em florestas dominadas por Araucaria angustifolia na RPPN Alto-Montana, Serra da Mantiqueira. Oecologia Australis 22(01): 74-88. https://doi. org/10.4257/oeco.2018.2201.07

Melo GL, Sponchiado J, Cáceres NC (2012) Use of camera-traps in natural trails and shelters for the mammalian survey in the Atlantic Forest. Iheringia. Série Zoologia 102(1): 88-94. https://doi.org/10.1590/S0073-47212012000100012

Melo FP, Arroyo-Rodríguez V, Fahrig L, Martínez-Ramos M, Tabarelli M (2013) On the hope for biodiversity-friendly tropical landscapes. Trends in Ecology \& Evolution 28(8): 462-468. https://doi.org/10.1016/j.tree.2013.01.001 
Miranda F, Bertassoni A, Abba AM (2014). Myrmecophaga tridactyla. The IUCN Red List of Threatened Species 2014: e.T14224A47441961.

Morrison JS, Sechrest W, Diner-Stein E, Wilcove DS, Lamoureux JF (2007) Persistence of large mammal faunas as indicators of global human impacts. Journal of Mammalogy 88(6): 1363-1380. https://doi.org/10.1644/06-MAMM-A-124R2.1

Myers N, Mittermeier RA, Mittermeier CG, Fonseca GAB, Kent J (2000) Biodiversity hotspot for conservation priorities. Nature 403(6772): 853-858. https://doi. org/10.1038/35002501

Oliveira G, Diniz-Filho JAF, Bini LM, Rangel TFL (2009a) Conservation biogeography of mammals in the Cerrado biome under the unified theory of macroecology. Acta Oecologica 35(5): 630-638. https://doi.org/10.1016/j.actao.2009.05.011

Oliveira VB, Câmara EM, Oliveira LC (2009b) Composição e caracterização da mastofauna de médio e grande porte do Parque Nacional da Serra do Cipó, Minas Gerais, Brasil. Mastozoología Neotropical 16: 355-364. https://doi.org/10.1590/S167606032010000300019

Paglia AP, Fonseca GAB, Rylands AB, Herrmann G, Aguiar LMS, Chiarello AG, Leite YLR, Costa LP, Siciliano S, Kierulff MCM, Mendes SL, Tavares VC, Mittermeier RA, Patton JL (2012) Lista anotada dos mamíferos do Brasil. $2^{\text {a }}$ ed. Occasional Paper in Conservation Biology. Conservation International, Arlington, $76 \mathrm{pp}$.

Paschoal AMO, Massara RL, Santos JL, Chiarello AG (2012) Is the domestic dog becoming an abundant species in the Atlantic forest? A study case in southeastern Brazil. Mammalia 76(1): 67-76. https://doi.org/10.1515/mammalia-2012-0501

Reboita MS, Rodrigues M, Silva LF, Alves MA (2015) Aspectos climáticos do estado de minas gerais (climate aspects in minas gerais state). Revista Brasileira de Climatologia 17: 206-226. https://doi.org/10.5380/abclima.v17i0.41493

Rocha CE, Dalponte JC (2006) Composição e caracterização da fauna de mamíferos de médio e grande porte em uma pequena reserva de Cerrado em Mato Grosso do Sul, Brasil. Revista Árvore 30(4): 669-678. https://doi.org/10.1590/S0100-67622006000400021

Rocha EC, Brito D, Silva J, Bernardo PVDS, Juen L (2018) Effects of habitat fragmentation on the persistence of medium and large mammal species in the Brazilian Savanna of Goiás State. Biota Neotropica 18(3): 3. https://doi.org/10.1590/1676-0611-bn-2017-0483

Rodrigues FHG, Silveira L, Jácomo ATA, Carmignotto AP, Bezerra AMR, Coelho DC, Garbogini H, Pagnozzi J, Hass A (2002). Composição e caracterização da fauna de mamíferos do Parque Nacional das Emas, Goiás, Brasil. Revista Brasileira de Zoolologia 19(2):589-60. https://doi.org/10.1590/S0101-81752002000200015

Silva JMC, Bates JM (2002) Biogeographic patterns and conservation in the South American Cerrado: A tropical savanna hotspot. Bioscience 52(3): 225-233. https://doi. org/10.1641/0006-3568(2002)052[0225:BPACIT]2.0.CO;2

Silva MMF, Diniz-Filho JAF (2008) Extinction of mammalian populations in conservation units of the Brazilian Cerrado by inbreeding depression in stochastic environments. Genetics and Molecular Biology 31(3): 800-803. https://doi.org/10.1590/S141547572008000400030 
Silva JF, Farinas MR, Felfili JM, Klink CA (2006) Spatial heterogeneity, land use and conservation in the Cerrado region of Brazil. Journal of Biogeography 33(3): 524-535. https:// doi.org/10.1111/j.1365-2699.2005.01422.x

Terborgh J (2000) The fate of tropical forests: A matter of stewardship. Conservation Biology 14(5): 1358-1361. https://doi.org/10.1046/j.1523-1739.2000.00136.x

Trolle M, Bissaro MC, Prado HM (2007) Mammal survey at a ranch of the Brazilian Cerrado. Biodiversity and Conservation 16(4): 1205-1211. https://doi.org/10.1007/s10531006-9106-X

Whittaker R, Araújo MB, Jepson P, Ladle RJ, Watson JEM, Willis KJ (2005) Conservation biogeography: Assessment and prospect. Diversity \& Distributions 11(1): 3-23. https:// doi.org/10.1111/j.1366-9516.2005.00143.x 